\title{
MESSAGE FROM PRESIDENT, AMERICAN WELDING SOCIETY
}

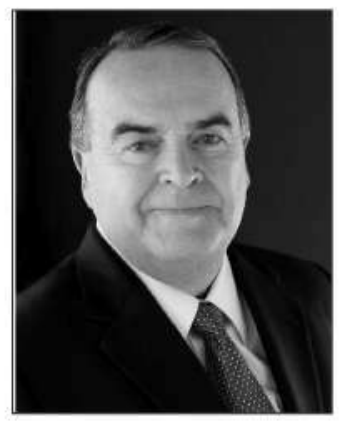

As 2014 President of the American Welding Society, I am extremely pleased and proud that AWS is again participating in the fast-growing Weld India exhibition, to be held April 10-12, 2014, at PragathiMaidan in New Delhi. We are especially excited about this year's show because, for the first time, it is being held with full sponsorship of our FABTECH exhibition, which has proven so successful in North America. FABTECH is co-organized by five industry-leading associations: the American Welding Society; the Fabricators \& Manufacturers Association, International; SME; the Precision Metalforming Association; and the Chemical Coaters Association International.

It has long been clear that the Indian market for welding equipment and consumables is one of the largest and most rapidly developing in the world. AWS sees this in its own membership statistics, which show that India has the largest AWS membership base outside the United States. To serve our thousands of members in India and all Indian welding interests, AWS entered into a cooperative publishing arrangement with the Indian Institute of Welding several years ago, where each issue of the Indian Welding Journal carries a special AWS Section of welding technology and news. The Indian Institute of Welding is deserving of great praise for supporting India's surge of industrial and technical development in the area of metal joining.

We also offer congratulations to the Indian Institute of Welding for organizing, at the same time and place, a major International Congress of the International Institute of Welding (IIW). Under the theme of "Advancement in Welding, Cutting and Surfacing Technologies for Improved Economy, Reliability and Sustainable Environment," the Congress will draw hundreds of delegates from around the world and will offer an environment for significant international cooperation in the welding industrial and research community. As one of the founding members of IIW, AWS applauds both IIW and the Indian Institute of Welding on continuing this strong tradition of technology development through this International Congress.

We look forward to meeting each of you here in New Delhi, and we wish the Indian Institute of Welding and IIW the greatest success in the notable exhibition and congress taking place this week.

\section{Dean R. Wilson}

President,

American Welding Society 